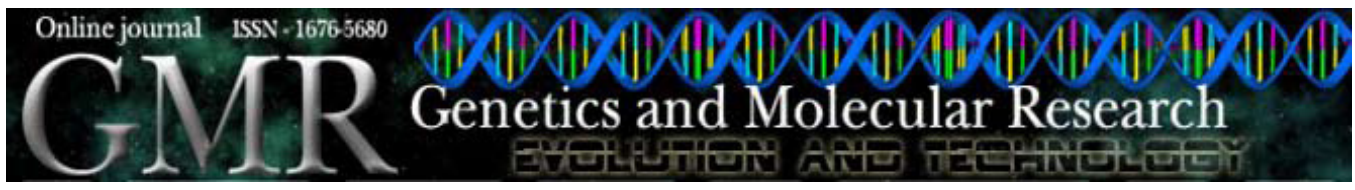

\title{
Schistosome/mollusk: genetic compatibility
}

\author{
A.L.D. Oliveira ${ }^{1,4,5}$, D. Da Silva ${ }^{2}$, E.M. Zanotti-Magalhaes ${ }^{3}$, \\ A.Z. Abdel-Hamid ${ }^{6}$, J.T. Ribeiro-Paes ${ }^{2}$ \\ ${ }^{1}$ Interunidades em Biotecnologia, Universidade de São Paulo, São Paulo, SP, Brasil \\ ${ }^{2}$ Departamento de Ciências Biológicas, Universidade Estadual Paulista, Assis, \\ SP, Brasil \\ ${ }^{3}$ Departamento de Parasitologia, Instituto de Biologia, \\ Universidade Estadual de Campinas, Campinas, SP, Brasil \\ ${ }^{4}$ Departamento de Saúde, ADR-Biomavale, Assis, SP, Brasil \\ ${ }^{5}$ Departamento de Ciências da Saúde, Universidade Paulista, Assis, SP, Brasil \\ ${ }^{6}$ Medicinal Chemistry Department, National Research Centre, Dokki, Cairo, Egypt \\ Corresponding author: J.T. Ribeiro-Paes \\ E-mail: olivaldo3@yahoo.com.br
}

Genet. Mol. Res. 7 (2): 518-526 (2008)

Received April 14, 2008

Accepted May 21, 2008

Published June 10, 2008

\begin{abstract}
Schistosomiasis remains one of the most prevalent parasitic infections and has significant economic and public health consequences in many developing countries. Economic development and improvement in standard of living in these countries are dependent on the elimination of this odious disease. For the control of Schistosomiasis, understanding the host/parasite association is important, since the host parasite relationship is often complex and since questions remain concerning the susceptibility of snails to infection by respective trematodes and their specificity and suitability as hosts for continued parasite development. Thus, the long term aim of this research is to learn more about the genetic basis of the snail/parasite relationship with the hope of finding novel ways to disrupt the transmission of this disease. In the current research, genetic variability among susceptible and resistant strains within and between Biomphalaria glabrata and B. tenagophila was investigated using RAPD-PCR. The results indicate great genetic variations within the two snail species using three different primers
\end{abstract}


(intrapopulational variations), while specimens from the same snail species showed few individual differences between the susceptible and resistant strains (interpopulational variation).

Key words: Biomphalaria; Schistosomiasis; RAPD-PCR; Genetic variability; Polymorphism

\section{INTRODUCTION}

Biomphalaria snails are the most common freshwater intermediate host snail prevailing in developing countries and have been recognized as the intermediate host for $S$. mansoni, which is responsible for wide spread schistosomiasis infections in humans. B. glabrata and B. tenagophila play an increasingly important role in transmission of $S$. mansoni in Brazil, and they are considered to be potential hosts of the schistosome parasite. The understanding of the genetic basis for schistosome resistance/or susceptibility in these snail species is especially important, because schistosome eradication programs may benefit from the knowledge of the genetic polymorphism of these snails since association between hosts and parasite tend to generate and maintain genetic polymorphism (May, 1985), as has been predicted in models of schistosome-snail interactions (Morand et al., 1996).

Several molecular biology techniques for studies of genetic variability in schistosomiasis vectors have been used (Miller et al., 1996; Spatz et al., 1999; Knight et al., 1991, 2000; Jannotti-Passos and Souza, 2000; Vidigal et al., 2000, 2001; Caldeira et al., 2000, 2001; Souza and Passos, 2001; Tuan and Bortolato, 2001).

Many attempts have been made to define markers for susceptibility/resistance in either B. glabrata (Mulvey and Vrijenhoek, 1982; Mulvey and Woodruff, 1985; Sire et al., 1999; Knight et al., 1999) or B. tenagophila (Abdel-Hamid et al., 1999). Most attempts involved linkage analysis by examining pigmentation and allozyme phenotypes in resistant and susceptible snails. To date, no single association between such markers and linkage to the resistant phenotype has been identified in these snail species.

Recently, several investigators showed that random amplified polymorphic DNApolymerase chain reaction (RAPD-PCR) is useful for distinguishing between and within different Biomphalaria snail species (Abdel-Hamid et al., 1999; Knight et al., 1999; Kristensen et al., 1999; Sire et al., 1999).

Due to the high applicability of RAPD-PCR and the quality of the results obtained, we have used this technique to investigate the intra- and interpopulational variability related to susceptibility and resistance to $S$. mansoni infection of both B. glabrata and B. tenagophila and to detect genetic markers associated with resistant/or susceptible snails which may be responsible for schistosome resistance in Biomphalaria snails.

\section{MATERIAL AND METHODS}

\section{Intermediate host snails}

The separation of schistosome resistant and susceptible strains from both B. glabrata (BH strain) and B. tenagophila (SJ strain) was performed according to the method described by Zanotti-Magalhaes et al. (1997). The snails originated from Campinas (São Paulo, Brazil) 
and had been maintained in our laboratory under suitable environmental conditions.

In selecting for resistant stocks, snails that remained uninfected after two parasitic exposures (10 miracidia/snail) were isolated and reared singly for selfing. Also, in selecting for susceptible stocks, unexposed progeny of snails from which exposed test groups yielded high infection frequencies, were isolated and reared singly for selfing. Resistant and susceptible snails were used in the present study to identify RAPD fragments that could be associated with resistance.

\section{Molecular analysis}

DNA was extracted from the tip of the head foot region of snails individually, using lysis buffer containing 2\% CTAB (Winnepenninckx et al., 1993 and modified by AbdelHamid et al., 1999). DNA concentration and purity was determined spectrophotometrically (Spectrophotometer Ultrospec III - Pharmacia, UK) based on absorbance at 260 and $280 \mathrm{~nm}$, and by $2.0 \%$ agarose gel electrophoresis using the gel photodocumentation system (EDAS) DC 120 Zoom Digital Camera (Eastman Kodak, NY, USA).

\section{DNA amplification by RAPD-PCR}

The genotypes of the resistant and susceptible strains of the two snail species B. glabrata and B. tenagophila were determined with 5 arbitrary 10-mer primers by RAPD-PCR as in the method of Simpson et al. (1993), with some modifications. An amount of 2 ng genomic DNA was amplified with a PTC 200 Peltier Thermal Cycler (MJ Research, USA) using RAPD-PCR. Each reaction was carried out in a final volume of $20 \mu \mathrm{L}$ containing 1 unit Taq DNA polymerase (GibcoBRL, MD, USA), 1X PCR buffer, $0.2 \mathrm{mM}$ of each dNTP, and 7 pmol of each random primer (Gibco-BRL) [1 (5'-GTGCTACGT-3'), 2 (5'-CAGGCCCTTC-3') and 3 (5'-GGTCCCTGAC-3')]. The amplification conditions were as follows: 1 cycle at $95^{\circ} \mathrm{C}$ for $5 \mathrm{~min}, 2$ cycles at $95^{\circ} \mathrm{C}$ for $30 \mathrm{~s}$, at $30^{\circ} \mathrm{C}$ for $2 \mathrm{~min}$ and at $72^{\circ} \mathrm{C}$ for $1 \mathrm{~min}$, and 33 cycles during which the annealing temperature was changed to $40^{\circ} \mathrm{C}$ and the time of the extension step was increased to $5 \mathrm{~min}$ during the final cycle. As control, PCR were run without DNA genome. After DNA thermal cycle, PCR products were analyzed by using polyacrylamide gel electrophoresis and silver stained to resolve amplified fragments as described by Santos et al. (1993).

Intra- and interpopulational genetic variability among B. glabrata and B. tenagophila was evaluated by analyzing the electrophoretic band patterns obtained on the gels and by determining the similarity coefficient as described by Dice (1945).

\section{RESULTS}

Susceptibility or resistance to $S$. mansoni infection within Biomphalaria snails was studied starting 30 days post-infection and continuing thereafter weekly up to 10 weeks after miracidia exposure. The results point out that about 9 and $93 \%$ of the examined B. glabrata and B. tenagophila snails were resistant, in contrast to 91 and $7 \%$ of these snails yielding high infection frequencies, respectively (Figure 1). The curves representing percentages of susceptible snails showed notable levels starting at the 6th week post-infection, which reached the highest peaks by approximately the 8th week. On the other hand, the curves of refractory snails gradually decreased toward the 8 th week and up to the 8 th week post-infection no changes in percent- 
ages of refractory snails occurred, with no differences being noted up to the 10th week. The ratio of susceptibility/resistance within the same species at a time was fixed, although the number of snails could change depending on the increasing of mortality within susceptible ones.

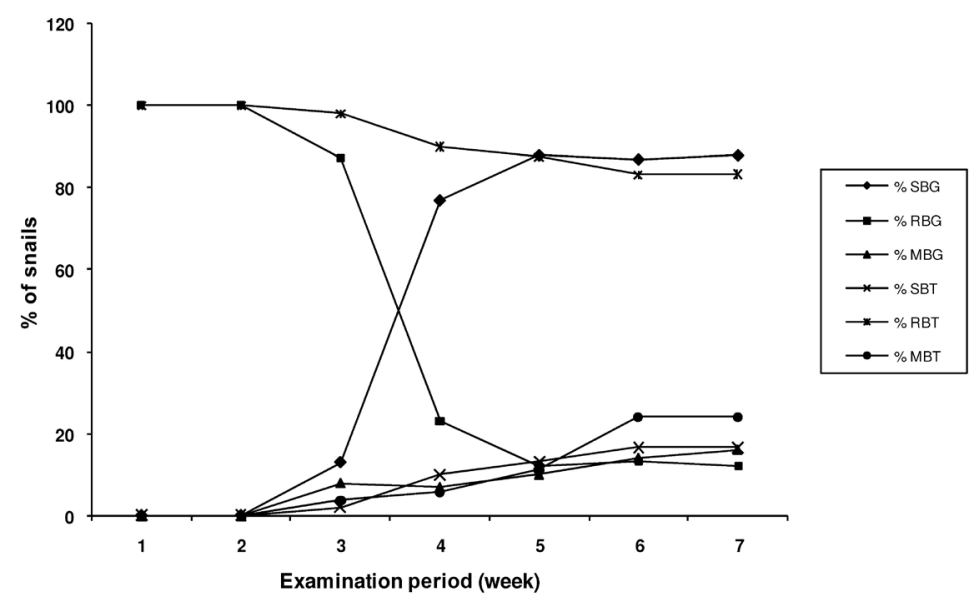

Figure 1. Diagrammatic representation of susceptibility/resistance of Biomphalaria glabrata and B. tenagophila to Schistosoma mansoni. $\mathrm{SBG}=$ susceptible $B$. glabrata; $\mathrm{RBG}=$ resistant $B$. glabrata $; \mathrm{MBG}=$ mortality of $B$. glabrata $; \mathrm{SBT}=$ susceptible $B$. tenagophila $; \mathrm{RBT}=$ resistant $B$. tenagophila $; \mathrm{MBT}=$ mortality of $B$. tenagophila .

The results also indicate that despite the low efficiency of $B$. tenagophila as a host (experimental infection rates are less than $9 \%$ as shown in Figure 1, in contrast with high infection rates of $B$. glabrata), this species is an important schistosomiasis vector in Brazil and plays a potential role together with $B$. glabrata in transmission of $S$. mansoni in different regions.

From a genetic point of view, the results obtained by Dice's coefficient point out that, by using different primers, the mean percentages of shared bands among all pairs from both susceptible and resistant strains within the same species B. glabrata or B. tenagophila ranged from 93 to $95 \%$ and from 96 to $97 \%$, respectively, in contrast to 85 to $87 \%$ and 80 to $83 \%$ among all the pairs of the two different snail species. From Tables 1, 2 and 3, it is also noted that the most related individuals belong to the same snail species either B. glabrata or B. tenagophila with the similarity coefficient ranging from 0.93 to 0.1 , while snails from different species showed great genetic variations with a similarity coefficient ranging from 0.67 to 0.77 .

Table 1. Dice's similarity coefficient $\left({ }^{*} S\right)$ of the profile bands between susceptible and resistant strains of both Biomphalaria glabrata and B. tenagophila using primer 1 (5'-AGTGCTACGT-3').

\begin{tabular}{|c|c|c|c|c|}
\hline Snail strain & $\begin{array}{l}\text { B. tenagophila } \\
\text { susceptible }\end{array}$ & $\begin{array}{l}\text { B. tenagophila } \\
\text { resistant }\end{array}$ & $\begin{array}{l}\text { B. glabrata } \\
\text { susceptible }\end{array}$ & $\begin{array}{l}\text { B. glabrata } \\
\text { resistant }\end{array}$ \\
\hline B. tenagophila susceptible & 1.0 & 0.94 & 0.81 & 0.72 \\
\hline B. tenagophila resistant & 0.94 & 1.0 & 0.72 & 0.85 \\
\hline B. glabrata susceptible & 0.81 & 0.72 & 1.0 & 0.95 \\
\hline B. glabrata resistant & 0.72 & 0.77 & 0.95 & 1.0 \\
\hline
\end{tabular}


Table 2. Dice's similarity coefficient $\left({ }^{*} \mathrm{~S}\right)$ of the profile bands between susceptible and resistant strains of both Biomphalaria glabrata and B. tenagophila using primer 2 (5'-CAGGCCCTTC-3').

\begin{tabular}{lcccc}
\hline Snail strain & $\begin{array}{c}\text { B. tenagophila } \\
\text { susceptible }\end{array}$ & $\begin{array}{c}\text { B. tenagophila } \\
\text { resistant }\end{array}$ & $\begin{array}{c}\text { B. glabrata } \\
\text { susceptible }\end{array}$ & $\begin{array}{c}\text { B. glabrata } \\
\text { resistant }\end{array}$ \\
\hline B. tenagophila susceptible & 1.0 & 0.93 & 0.80 & 0.67 \\
B. tenagophila resistant & 0.93 & 1.0 & 0.78 & 0.82 \\
B. glabrata susceptible & 0.80 & 0.78 & 1.0 & 0.94 \\
B. glabrata resistant & 0.67 & 0.82 & 0.94 & 1.0 \\
\hline
\end{tabular}

${ }^{*} \mathrm{~S}=2 \mathrm{a} / 2 \mathrm{a}+\mathrm{b}+\mathrm{c}$, where: $\mathrm{a}=$ the number of shared bands between two individuals; $\mathrm{b}=$ the bands present in the 1 st and not in the 2 nd, and $\mathrm{c}=$ the bands present in the 2 nd and not in the 1 st.

Table 3. Dice's similarity coefficient $(* S)$ of the profile bands between susceptible and resistant strains of both Biomphalaria glabrata and B. tenagophila using primer 3 (5'-GGTCCCTGAC-3').

\begin{tabular}{lcccc}
\hline Snail strain & $\begin{array}{c}\text { B. tenagophila } \\
\text { susceptible }\end{array}$ & $\begin{array}{c}\text { B. tenagophila } \\
\text { resistant }\end{array}$ & $\begin{array}{c}\text { B. glabrata } \\
\text { susceptible }\end{array}$ & $\begin{array}{c}\text { B. glabrata } \\
\text { resistant }\end{array}$ \\
\hline B. tenagophila susceptible & 1.0 & 0.93 & 0.79 & 0.71 \\
B. tenagophila resistant & 0.97 & 1.0 & 0.76 & 0.77 \\
B. glabrata susceptible & 0.79 & 0.76 & 1.0 & 0.95 \\
B. glabrata resistant & 0.71 & 0.77 & 0.95 & 1.0 \\
\hline
\end{tabular}

$* \mathrm{~S}=2 \mathrm{a} / 2 \mathrm{a}+\mathrm{b}+\mathrm{c}$, where: $\mathrm{a}=$ the number of shared bands between two individuals; $\mathrm{b}=$ the bands present in the 1 st and not in the 2 nd, and $\mathrm{c}=$ the bands present in the 2 nd and not in the 1 st.

The results also show that the data analyzed using primer 2 displayed more variation than with both primer 1 and primer 3. Despite the homogeneity of most bands, among the susceptible and resistant strains within the B. glabrata snail species, the genomic DNA amplified with primer 1 showed a polymorphic band of nearly $4060 \mathrm{bp}$ only in the susceptible strain, as shown in Figure 2, while the amplification results of genomic DNA of the same snail species with primers 2 and 3 pointed out a polymorphic marker of $1100 \mathrm{bp}$ in the susceptible strain also (Figures 3 and 4).
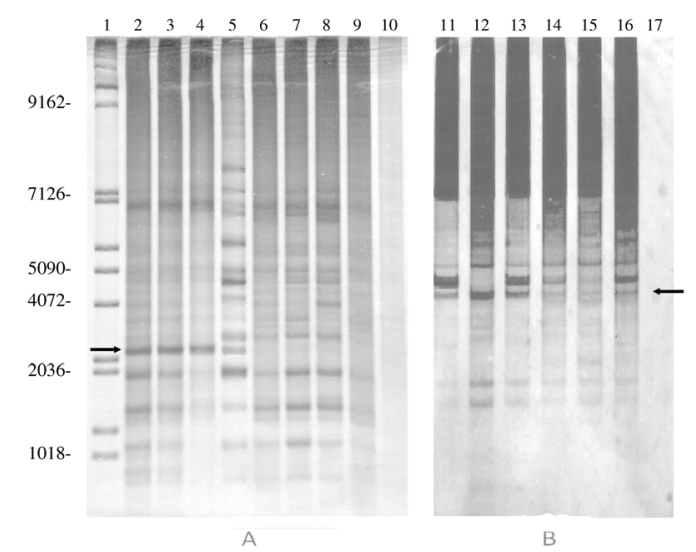

Figure 2. Random-amplified PCR of genomic DNA of two different snail strains (resistant and susceptible) within Biomphalaria glabrata and B. tenagophila species using arbitrary primer 1 (5'-AGTGCTACGT -3'). A. Lane 1, 1-kb DNA Ladder; lanes 2-4, individual of susceptible B. tenagophila; lane 5, Pool S, S1, S2 and S3; lane 6, Pool R, R1, R2 and R3; lanes 7-9, individual of resistant B. tenagophila; lane 10, negative control. B. Lanes 11, 12, individual of resistant B. glabrata; lane 13, pool of resistant B. glabrata; lane 14, pool of susceptible B. glabrata; lanes 15, 16, individual of susceptible B. glabrata; lane 17, negative control. 


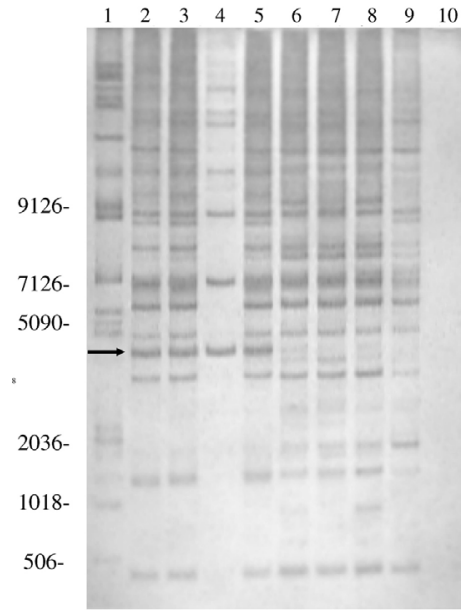

A

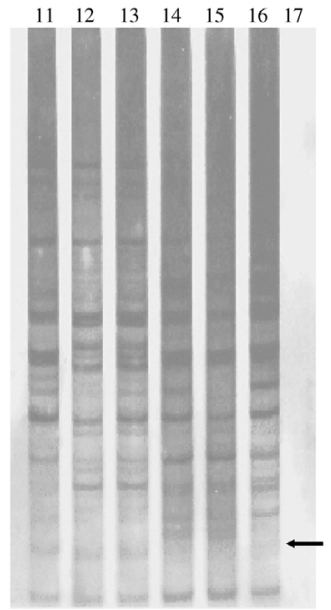

$\mathrm{B}$

Figure 3. Random-amplified PCR of genomic DNA of two different snail strains (resistant and susceptible) within Biomphalaria glabrata and B. tenagophila species using arbitrary primer 2 (5'-CAGGCCCTTC-3'). A. Lane 1, 1-kb DNA Ladder; lanes 2-4, individual of susceptible B. tenagophila; lane 5, Pool S, S1, S2 and S3; lane 6, Pool R, R1, R2 and R3; lanes 7-9, individual of resistant B. tenagophila; lane 10, negative control. B. Lanes 11, 12, individual of resistant B. glabrata; lane 13, pool resistant of B. glabrata; lane 14, pool susceptible of B. glabrata; lanes 15, 16, individual of susceptible B. glabrata; lane 17, negative control.
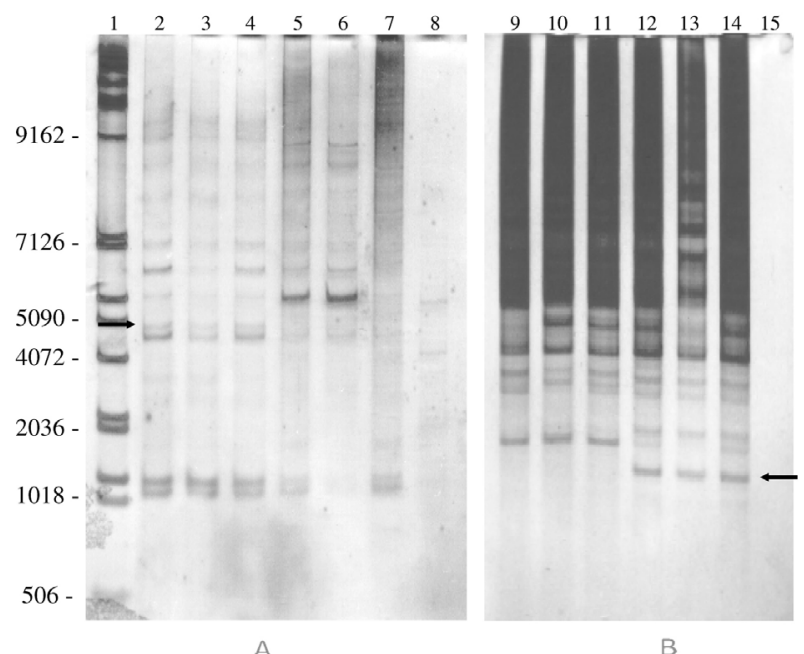

B

Figure 4. Random-amplified PCR of genomic DNA of two different snail strains (resistant and susceptible) within Biomphalaria glabrata and B. tenagophila species using arbitrary primer 3 (5'-GGTCCCTGAC-3'). A. Lane 1, 1-kb DNA Ladder; lanes 2, 3, individual of susceptible B. tenagophila; lane 4, pool of susceptible B. tenagophila; lane 5, pool of resistant $B$. tenagophila; lanes 6,7 , individual of resistant $B$. tenagophila; lane 8 , negative control; B. Lanes 9, 10, individual of resistant B. glabrata; lane 11, pool of resistant B. glabrata; lane 12, pool of susceptible $B$. glabrata; lanes 13, 14, individual of susceptible B. glabrata; lane 15, negative control. 
Primers 1, 2, and 3 revealed a single polymorphic band of approximately 5056, 3136, and $5041 \mathrm{bp}$, respectively (Figures 2-4) in the susceptible strain of the B. tenagophila snail species.

Although, the specimens from different strains within the same species showed few individual differences, the amplified bands with primers 1,2 , and 3 of the corresponding strains between the two different snail species B. glabrata and B. tenagophila showed many polymorphic markers (Figures 2-4).

These results represent a starting point for the identification and isolation of genes specifically related to susceptibility and supporting the previous hypotheses that RAPD-PCR is a suitable and efficient methodological approach to the analysis of genetic variability of schistosomiasis vectors.

\section{DISCUSSION}

The results show that $B$. tenagophila is not so efficient as intermediate host, compared to B. glabrata, since the experimental infection rates are less than $7 \%$ as seen in Figure 1, in contrast to high infection rates of $B$. glabrata. These results support the data obtained by Brasio et al. (1985) who found that B. glabrata has a more efficient power of attraction to miracidia than B. tenagophila. Paraense et al. (1983) also pointed out that "the presence of $B$. glabrata is coincident with the schistosomiasis transmission". Thus, these observations have important epidemiological implications, as Zanotti-Magalhães et al. (1997) demonstrated that the human disease caused by $S$. mansoni that use B. glabrata as an intermediate host is more dangerous than that involving $B$. tenagophila. Despite all the epidemiological implications and also despite the low efficiency as a vector of $S$. mansoni, $B$. tenagophila plays a potential and important role together with $B$. glabrata in transmission of schistosomiasis in different Brazilian regions. In view of all these findings, both B. glabrata and B. tenagophila snail species were chosen in the current study for investigating intra- and interpopulational genetic variation and to detect some genetic markers associated with resistant snail species.

We also observed in the present study that susceptibility/resistance to Schistosoma mansoni infection within both B. glabrata and B. tenagophila was only considered at 8 th week post-infection and up to this time point for selecting resistant snail stock. It is also well recognized that, with time, refractory snails to $S$. mansoni infection may gradually decrease and vice versa, where susceptible ones increase up to the 8th week post-infection. The possibilities explaining this situation could be a delay in development of the parasite within some snail strains, since susceptibility or resistance of the snails to $S$. mansoni has mainly been claimed to be dependent on host genetic background or results from the interaction between the gene products of the mollusk and the parasite as declared previously by both Richards and Merritt Jr. (1972) and Richards and Shade (1987).

In the present study, the identification of polymorphic bands was based on the comparison of the band patterns on the same gel for the two strains, and only those detected in all individuals of the same strain and in the pool were considered polymorphic (Larson et al., 1996).

A possible existence of transposable elements in the snails opens new perspectives in the approach for transfection of sequences with incorporation into the snail genome (Richards et al., 1992). The markers or genomic sequences associated with resistance could be useful in the production of transgenic snails. The perspective of the acquisition of transgenic snail strains resistant to $S$. mansoni infection implies over coming many theoretical difficulties, especially the experimental ones. In spite of that, such methodological approach presents interesting perspectives (Lardans and Dissous, 1998) that, in association with other measures, 
will allow the elaboration of new strategies for the control of schistosomiasis.

The amplified markers that were found only in resistant strains within B. tenagophila and segregate between the two snail species could be responsible for the resistance of these snails to schistosome parasite infection, and should contribute to a better understanding of the correlations between vectors, parasites and transmission of the disease. This notion supports the previous results obtained by Brasio et al. (1985) who declared that B. tenagophila has low efficiency as an intermediate host for $S$. mansoni. In contrast, the absence of such markers in the corresponding individuals of $B$. glabrata could be responsible for the high efficiency of these snails in transmission of schistosomiasis in humans. These suggestions are in line with the finding of both Paraense et al. (1983) and Zanotti-Magalhaes et al. (1997) who reported that B. glabrata has a high efficiency in the transmission of schistosomiasis.

This approach has indeed attempted to add more to our knowledge about the genetic diversity of both snail species in the field and their roles in transmission of schistosomiasis in different regions in Brazil. It is anticipated that the development of molecular markers associated with resistant/susceptible phenotypes should lead to a thorough strategy for the control of schistosomiasis disease.

\section{ACKNOWLEDGMENTS}

Research supported by Fundação de Amparo à Pesquisa do Estado de São Paulo (FAPESP). The authors are grateful to Dr. Luiz Cândido Souza Dias and Dr. Vanderlei Rodrigues for continuous advice, discussions and critical suggestions.

\section{REFERENCES}

Abdel-Hamid AH, de Molfetta JB, Fernandez V and Rodrigues V (1999). Genetic variation between susceptible and nonsusceptible snails to Schistosoma infection using random amplified polymorphic DNA analysis (RAPDs). Rev. Inst. Med. Trop. São Paulo 41: 291-295.

Brasio BC, Magalhães LA, Miller J and Carvalho JF (1985). Atração de miracídios de Schistosoma mansoni por hospedeiros invertebrados. Comportamento de miracídios frente a girinos de Hyla fuscovaria. Rev. Saúde Publ. 19: 18-27.

Caldeira RL, Vidigal TH, Matinella L, Simpson AJ, et al. (2000). Identification of planorbids from Venezuela by polymerase chain reaction amplification and restriction fragment length polymorphism of internal transcriber spacer of the RNA ribosomal gene. Mem. Inst. Oswaldo Cruz 95: 171-177.

Caldeira RL, Vidigal TH, Simpson AJ and Carvalho OS (2001). Genetic variability in Brazilian populations of Biomphalaria straminea complex detected by simple sequence repeat anchored polymerase chain reaction amplification. Mem. Inst. Oswaldo Cruz 96: 535-544.

Dice LR (1945). Measures of the amount of ecological association between species. Ecology 26: 297-302.

Jannotti-Passos LK and de Souza CP (2000). Susceptibility of Biomphalaria tenagophila and Biomphalaria straminea to Schistosoma mansoni infection detected by low stringency polymerase chain reaction. Rev. Inst. Med. Trop. São Paulo 42: 291-294.

Knight M, Brindley PJ, Richards CS and Lewis FA (1991). Schistosoma mansoni: use of a cloned ribosomal RNA gene probe to detect restriction fragment length polymorphisms in the intermediate host Biomphalaria glabrata. Exp. Parasitol. 73: 285-294.

Knight M, Miller AN, Patterson CN, Rowe CG, et al. (1999). The identification of markers segregating with resistance to Schistosoma mansoni infection in the snail Biomphalaria glabrata. Proc. Natl. Acad. Sci. U. S. A. 96: 1510-1515.

Knight M, Ongele E and Lewis FA (2000). Molecular studies of Biomphalaria glabrata, an intermediate host of Schistosoma mansoni. Int. J. Parasitol. 30: 535-541.

Kristensen TK, Yousif F and Raahauge P (1999). Molecular characterisation of Biomphalaria spp in Egypt. J. Mollus. Stud. 65: 133-136.

Lardans V and Dissous C (1998). Snail control strategies for reduction of schistosomiasis transmission. Parasitol. Today 14: 413-417. 
Larson SE, Anderson PL, Miller AN, Cousin CE, et al. (1996). Use of RAPD-PCR to differentiate genetically defined lines of an intermediate host of Schistosoma mansoni, Biomphalaria glabrata. J. Parasitol. 82: 237-244.

May RM (1985). Host-parasite associations: their population biology and population genetics. In: Ecology and Genetics of Host-Parasite Interactions (Rollinson D and Anderson RM, eds.). Academic Press, London, 243-262.

Miller AN, Ofori K, Lewis F and Knight M (1996). Schistosoma mansoni: use of a subtractive cloning strategy to search for RFLPs in parasite-resistant Biomphalaria glabrata. Exp. Parasitol. 84: 420-428.

Morand S, Manning SD and Woolhouse ME (1996). Parasite-host coevolution and geographic patterns of parasite infectivity and host susceptibility. Proc. Biol. Sci. 263: 119-128.

Mulvey M and Vrijenhoek RC (1982). Population structure in Biomphalaria glabrata: examination of an hypothesis for the patchy distribution of susceptibility to schistosomes. Am. J. Trop. Med. Hyg. 31: 1195-1200.

Mulvey M and Woodruff DS (1985). Genetics of Biomphalaria glabrata: linkage analysis of genes for pigmentation, enzymes, and resistance to Schistosoma mansoni. Biochem. Genet. 23: 877-889.

Paraense WL, Alencar JTA and Corrêa LR (1983). Distribuição dos planorbídeos e prevalência da xistosomose mansoni no Estado do Espírito Santo. Mem. Inst. Oswaldo Cruz 78: 373-384.

Richards CS and Merritt JW Jr (1972). Genetic factors in the susceptibility of juvenile Biomphalaria glabrata to Schistosoma mansoni infection. Am. J. Trop. Med. Hyg. 21: 425-434.

Richards CS and Shade PC (1987). The genetic variation of compatibility in Biomphalaria glabrata and Schistosoma mansoni. J. Parasitol. 73: 1146-1151.

Richards CS, Knight M and Lewis FA (1992). Genetics of Biomphalaria glabrata and its effect on the outcome of Schistosoma mansoni infection. Parasitol. Today 8: 171-174.

Santos FR, Pena SD and Epplen JT (1993). Genetic and population study of a Y-linked tetranucleotide repeat DNA polymorphism with a simple non-isotopic technique. Hum. Genet. 90: 655-656.

Simpson AJG, Dias Neto E, Steindel M, Caballero OLSD, et al. (1993). The use of RAPDs for the analysis of parasites. In: DNA Fingerprinting: State of the Science (Pena SDJ, Chakraborty R, Epplen JT and Jeffreys AJ, eds.). Birkhauser, Verlag, Basel, 331-337.

Sire C, Durand P, Pointier JP and Theron A (1999). Genetic diversity and recruitment pattern of Schistosoma mansoni in a Biomphalaria glabrata snail population: a field study using random-amplified polymorphic DNA markers. $J$. Parasitol. 85: 436-441.

Souza CP and Passos LK (2001). Resistance of Biomphalaria occidentalis from Varzea das Flores dam, Minas Gerais, to Schistosoma mansoni infection detected by low stringency polymerase chain reaction. Mem. Inst. Oswaldo Cruz 96: 381-383.

Spatz L, Vidigal THDA, Caldeira RL, Dias Neto E, et al. (1999). Study of Biomphalaria tenagophila tenagophila, B. $t$. guaiabensis and $B$. occidentalis by polymerase chain reaction amplification and restriction enzyme digestion of the ribosomal RNA intergenic spacer regions. J. Moll. Stud. 65: 143.

Tuan R and Bortolato PC (2001). Genetic markers from Biomphalaria tenagophila (Gastropoda: Pulmonata: Planorbidae) obtained by the double stringency polymerase chain reaction technique. Mem. Inst. Oswaldo Cruz 96: 435-436.

Vidigal THDA, Caldeira RL and Simpson AJG (2000). Further studies on the molecular systematics of Biomphalaria snails from Brazil. Mem. Inst. Oswaldo Cruz 95: 57-66.

Vidigal THDA, Caldeira RL, Simpson AJG and Carvalho OS (2001). Identification of Biomphalaria havanensis and Biomphalaria obstructa populations from Cuba using polymerase chain reaction and restriction fragment length polymorphism of the ribosomal RNA intergenic spacer. Mem. Inst. Oswaldo Cruz 96: 661-665.

Winnepenninckx B, Backeljau T and De Wacbier R (1993). Extraction of high molecular weight DNA from molluscs. Trends Genet. 9: 407.

Zanotti-Magalhães EM, Magalhães LA and Carvalho JR (1997). Relação entre patogenicidade do Schistosoma mansoni em camundongos e a susceptibilidade do molusco vetor IV. Infecciosidade dos miracídios. Rev. Saúde Pública 29: 265-270. 